\section{Coloured Light for Motor-Car Headlights}

As many motorists use headlights giving coloured lights, an authoritative and scientific statement as to whether coloured light is better than white light for night driving or during fog has for long been desired. A report by an illumination committee of the Department of Scientific and Industrial Research (Technical Paper No. 20. London : H.M. Stationery Office) has now practically settled the question. Adequate evidence is given that in conditions of slight or thick fog the range of visibility of objects seen in the beam of the headlight is not increased by the use of coloured light obtained from the original white light by means of a filter. One investigator has put on record that in clear weather the range of visibility of an object is increased about 6 per cent by the use of a yellow filter. This result was obtained at a distance of about 900 feet; but at shorter distances, at which the motorist is more concerned to see objects, the advantage of the yellow filter, in any event small, is still smaller. There is no experimental evidence that the power of the oye to perceive contrasts of brightness in the presence of a dazzling light is enhanced if similar colour filters are placed over the dazzling light and over the light illuminating the objects viewed. The evidence as to whether the use of coloured light obtained from white light by means of a coloured filter enables the eye to detect contrasts of brightness more easily is conflicting. Recent investigations have shown that there is a slight advantage, but this is meonsistent with the measurements of earlier workers. There is evidence for a slight increase in the power of the eye to perceive the details of a pattern in black and white' by the use of yellow light obtained from white light by means of a filter.

\section{Technical Development and Manual Labour}

IN a paper read before the Royal Society of Arts on March 17 on "The Displacement of Labour by Machinery" and recently made available, Mr. H. D. Henderson discussed the subject of the effect of technical progress on employment. The contention that invention is now flowing in a direction which merely leads to the introduction of machinery so automatic that scarcely any labour is needed to operate was described as plausible but devoid of substance. The distinction, on which it rests, between mechanization which is in the main cooperative with labour and that which is in the main competitive with it is illusory, since all mechanization diminishes the amount of labour employed per unit of output, while the inventions which have done most in the past to stimulate economic activity have entriled an especially large economy in this respect. He believes that the old economic argument, which sought to prove that technical progress serves in the long run to expand rather than to contract the demand for labour, is still valid. Owing to change in population trends, however, the process of technical development is likely to be accompanied in the future by greater difficulties and more awkward problems of adjustment. These problems cannot be escaped by slowing down the rate of technical progress, so far as this depends on the extended use of machinery. Such action would only intensify our difficulties while depriving us of the benefits of mechanical advance.

\section{Organization of Human Society}

IN his Herbert Spencer Lecture at Oxford on May 27 entitled "Integrative Levels : a Revaluation of the Idea of Progress" (Oxford : Clarendon Press ; London : Oxford University Press, 1937. 2s. 6d. net), Dr. J. Needham discusses Spertcer's treatment of sociological problems in relation to the evolution of social organizations to meet the needs imposed by mechanization and the impact of science to day. $\mathrm{He}$ suggests that a democracy which produces is the form of society most in accord with what we know of the biological basis of human common life. Evolution is not yet finished, organization has not yet reached its highest level and we can see the next stage in the co-operative commonwealth of humanity, the socialization of the means of production. Every transition from the unconscious to the conscious implies a step from bondage to freedom from lower to higher level of organization, and Dr. Needham emphasizes that our present civilization is not in a state of stable equilibrium. The enormous advances in scientific knowledge and practical technique have made the economic system of Spencer an anachronism. $\mathrm{He}$ is of opinion that nothing short of the abolition of private ownership of resources and machines, the abolition of national sovereignties and the government of the world by a power proceeding from the class which must abolish classes will suit the technical situation of the twentieth century. The organization of human society is only as yet at the beginning of its inevitable triumphs.

\section{Preservation of Salcombe Hill}

IT has been agreed between the Rev. J. G. Cornish and the Sidmouth (Devon) Urban District Council that South Down Farm on Salcombe Hill and the adjacent South Combe Farm should be preserved in perpetuity as private open spaces. A similar agreement has been made with Dr. Vaughan Cornish concerning the eight hundred yards of cliff frontage to this property. Dr. Vaughan Cornish has also undertaken to maintain a right of way along the cliff even if falls of cliff destroy the existing path. These engagements have been made voluntarily by the Rev. Cornish and Dr. Cornish, and they ensure that the fields of the Salcombe Regis Valley will be preserved as an open space for all time. The Norman Lockyer Observatory is on the top of Salcombe Hill, and it is gratifying to know that, by one of these generous gifts, the fields on the south side of the road opposite to the Observatory are never to be used for building development.

\section{Further Gifts to Oxford from Lord Nuffield}

LORD NUFFIELD has offered $£ 1,000,000$ to the University of Oxford (including a site valued at $£ 100,000$ ) for the building of a new college to be devoted to the collaboration, particularly in social 
(including economic and political) studies, of theoretical students and practical men of affairs. The site is situated to the west of Oxford between Worcester College and Pembroke College. Two further bequests by Lord Nuffield include $£ 100,000$ for the erection and equipment of a new laboratory of physical chemistry and $£ 200,000$ for the erection of buildings at hospitals associated with the medical research scheme endowed by him in 1936 .

\section{Discovery of Teeth of Australopithecus}

AT the time of going to press, we have received a further communication from Dr. R. Broom, dated October 5, supplementing his letter under this title which appears on p. 681. He writes: "Since the above letter was written two weeks ago, four more teeth of Australopithecus have been discovered. Two are teeth of a very aged animal with the crowns almost completely worn off. One of these is a lower premolar, and the other a third left upper molar, but these are of little scientific value. The third tooth is a first upper incisor. Unfortunately, part of the crown is broken off and part of the root, but enough is preserved to show most of the structure. It is remarkably human. The width of the crown is about $10 \mathrm{~mm}$. and the whole length of the tooth probably about $32 \mathrm{~mm}$. The fourth tooth is the beautifully preserved crown of a right third upper molar. It agrees closely with the wisdom tooth of the type, but it is slightly more worn and has fewer corrugations. It probably belongs to the same individual as the third right lower molar tooth."

\section{Announcements}

THE Lord President of the Council has appointed Dr. G. M. B. Dobson, Lieut.-Colonel J. H. M. Greenly and Mr. S. K. Thornley to be members of the Advisory Council to the Committee of the Privy Council for Scientific and Industrial Research. Prof. A. Fowler, Sir Clement Hindley and Dr. T. Franklin Sibly have retired from the Council upon the completion of their terms of office.

THe first Radford Mather Lecture of the British Association will be given by the Right Hon. J. Ramsay MacDonald on Friday, October 22, at the Royal Institution, Albemarle Street, London, W.1, at 5 p.m. Mr. MacDonald will take as his subject "Science and the Community". The Norman Lockyer Lecture, on "Origins of Town Life in Britain : an Illustrated Review of Recent Evidence", will be given by Dr. R. E. Mortimer Wheeler in the Goldsmiths' Hall, Foster Lane, Cheapside, London, E.C.2, at 4 p.m. on Wednesday, November 24. Further information can be obtained from the Secretary, British Association, Burlington House, London, W.1.

The Iron and Steel Institute and the Institute of Metals have arranged to hold their 1938 autumn meetings in the United States, opening in New York jointly with the corresponding American Institutes on October 3. Technical sessions will be held on
October 3 and 4, and from then until October 21 visits will be made to various centres of technical interest in the United States. Further information can be obtained from the Secretary, Iron and Steel Institute, 28, Victoria Street, London, S.W.I.

THE Federation of Progressive Societies announces a series of fourteen lectures being given in the Conway Hall, Red Lion Square, W.C.1, at 8 p.m. Among the subjects and lecturers are: November 3 , eugenics and the class struggle, J. B. S. Haldane; November 10, sex and censorship, Norman Haire; January 5, 1938, the failure of intellectuals, Dora Russell ; February 2, the cultural basis for unity, John MacMurray. Particulars may be obtained from the hon. secretary of the Society, 4 Fitzroy Street, London, W.I.

THe following appointments and promotions have recently been made in the Colonial Service: B. de L. Inniss, agricultural superintendent, Gold Coast ; A. B. Lucy, agricultural officer, Malaya; A. F. Posnette, botanist, Agricultural Department, Gold Coast ; D. H. Welch, agricultural officer, Nigeria ; H. B. Burgess, assistant conservator of forests, Nigeria; J. H. Nelson Smith, assistant conservator of forests, British Honduras; P. R. Page, assistant conservator of forests, Nigeria ; C. I. Turner, veterinary officer, Malaya; G. K. Argles, manager, Fruit and Vegetable Development Scheme, Jamaica; E. G. A. Benson (assistant agricultural superintendent), agricultural superintendent, British Guiana; D. L. Blunt (director of agriculture, Cyprus), director of agriculture, Nyasaland; W. E. Freeman (late tobacco breeding officer, Mauritius), botanist, Agricultural Department, Nigeria ; E. F. S. Shepherd (botanist and mycologist, Agricultural Department, Mauritius), plant pathologist, Gold Coast ; J. P. Edwards (senior assistant conservator of forests), conservator of forests, Malaya; M. Crawford (Government veter. inary surgeon), deputy director (animal husbandry) and Government veterinary surgeon, Department of Agriculture, Ceylon; G. B. Simmins (veterinary research officer), senior veterinary research officer, Department of Agriculture and Fisheries, Palestine; M. A. Crane (chief draughtsman), research officer, Mechanical Engineering Department, Nigerian Railways; C. G. Fannin (district surveyor), chief surveyor, Kenya ; J. H. Haleblian (assistant chemist), chemist, Department of Antiquities, Palestine; A. S. McKinnon (assistant livestock officer, Veterinary Department, Tanganyika), agricultural officer, Veterinary and Agricultural Department, Somaliland; J. H. Nield (computer), district surveyor, Kenya; J. G. Reece (first assistant surveyor), deputy surveyor and deputy sub-intendant, Trinidad; H. Smith (assistant mechanical engineer, Public Works and Electricity Department, Zanzibar), inspector of machinery, Mines Department, Gold Coast; J. A. R. Stoyle (Government analyst, Mauritius), assistant Government analyst, Nigeria; W. G. W. Wilson (superintendent of workshops), chief mechanical engineer, Nigerian Railways. 